\title{
Effectiveness of Online Learning during the Covid-19 Pandemic: A Case of One University in Zimbabwe
}

\author{
Diocleciano Nhatuve, PhD \\ The University of Zimbabwe
}

Corresponding Mail: dirnhatuve@gmail.com

\begin{abstract}
This study sought to investigate on effectiveness of online teaching and learning during the Covid-19 Pandemic: A Case of one university in Zimbabwe. The study adopted quantitative approach in which 202 students were given an online questionnaire to fill. Data was analyzed through graphs to indicate the perception of students on effectiveness and challenges involved in the online teaching and learning. The study concludes that the e-teaching and e-learning adopted to minimize negative impact of Covid-19 Pandemic were not effective. High number of students (63\% and 14\%) reported that the whole process was frustrating as they could not learn effectively. Furthermore, students revealed that their failure was due to various challenges including inefficient strategies used by lecturers and difficulties to stablish and maintain relevant and fruitful interaction between lecturers and students. The learning process was monotonous. Lecturers could not convey adequate feedback and tests and assignments were not clear. To overcome challenges indicated by students, the study recommends that institutions of higher learning provide relevant equipment and educators be trained to develop competencies and skills for e-learning.
\end{abstract}

Keywords: Covid-19; E-teaching; E-learning; Universities; Southern African Region; challenges

\section{Introduction}

Development of science and technology imposes changes in different spheres of society, including administration, education and economy. The use of Information and Communication Technologies (ICT) has significant impact on education in that the exchange of information in teaching and learning has become easier and quicker than ever. Furthermore, teaching and learning processes have become more digital, anchored in online platforms. Geographical distance is no longer a challenge. As a result, teachers and learners experience new roles (Meneses, Fernandez \& Regana; Anderson, 2008b).

The outbreak of the Covid-19 pandemic (late 2019 and the year 2020) emboldened the relevance of the online teaching and learning. Due to this pandemic, following the World Health Organization guidelines, different countries adopted measures of lockdown to control and minimize the spread of the coronavirus. Schools, Universities and other Institutions were closed. Educators and students could not share the same physical space (classroom) for teaching and learning purposes. To mitigate the negative impact of the pandemic in the education sector, many countries adopted digital and online teaching and learning. However, the readiness for this alternative model of education was not the same for different institutions, due to socioeconomic circumstances. Institutions that had created conditions and encouraged the online learning even before the outbreak of the pandemic conducted it better than institutions and communities that were not well equipped for the online learning, and were adopting it for the first time.

Anderson (2008a) and Ally (2008), in theory and practice of online learning, outline aspects and concepts featuring the teaching and learning in online contexts. Firstly, Anderson (2008a, p. 44-52) described online education as a learner, knowledge, assessment and community-centered process. Briefly, the conception of online teaching and learning highlights, above all, learner's role in the process of learning (his/her activities, attitudes, commitment and motivation). However, "learnercentered contexts must also meet the needs of the 
teacher, of the institution and of the larger society that provides support for the student, the institution as well as for the particular needs of individual learners" (p.47). Knowledge produced and/or developed online must not be isolated. Its quality and relevance depends on its connections and relations. Therefore, learners need to develop critical thinking and capacity to work independently and at the same time solve problems collaboratively.

Ally (2008, p. 17-18), on the other hand, outlines benefits of online teaching and learning for both teachers/lecturers and learners. The advantage of online learning is its flexibility in terms of time and space; students can learn at any time, from any place and with a myriad of resources to choose from. Online materials allow smooth and relevant asynchronous learning using up-to-date books and articles, while the synchronous online learning allows the interaction between learners and their instructors.

\section{Online Teaching and Learning}

The use of technology, particularly the Internet, is changing peoples' lives profoundly. It changes traditions of working, doing business, teaching, learning and communicating. People keep isolated at home, at school or at work, but connected and in permanent contact with millions of other people online. This is the new and attractive dynamic for online society. The area of education is not an exception. It is one of the most affected areas in which almost everything changes, including traditional modus operandi which is replaced by modern approaches of teaching and learning (Davis, Little \& Stewart, 2008; Bates, 2017). Environment and infrastructures used for face-to-face teaching and learning are replaced by digital and virtual environments to which strategies and material used for face-to-face teaching and learning can no longer be used (Moreira, 2018; Moreira \& Rigo, 2018).

Material and interaction approaches also change as online teaching and learning imply specific material that will motivate students to learn and find supplementary resources (Ally, 2008). The materials include texts, audios, pictures and videos which are available anytime and anywhere and are convenient to the student.

The interactions used for face-to-face in a physical environment, most of the time in the physical classroom, are now conducted through digital and online platforms. The advantage is that the current interaction knows no limits of time and space. It can be synchronous and/or asynchronous. According to Mendes et al. (2018, p. 11), whilst asynchronous communication allows and promotes flexibility in terms of space and time, synchronous sessions are done in groups, most of the time for presentations and discussion through e-facilities.

Learning activities that used to be done in class are replaced by e-activities done in a virtual environment online (Brenton, in Fry, Ketteridge, Marshall, 2009) in which students have a diversity of learning materials designed for different styles and strategies of learning (Brenton in Fry, Ketteridge, Marshall, 2009). If learning activities, strategies and environment change, then assessment cannot remain the same (Amante \& Oliveira, 2019). In online teaching and learning, the know-how and abilities to solve problems are the most relevant skills to develop and assess. Assessment done by lecturers, students, independent entities and society at large, "[serves] to motivate, inform and provide feedback to both learners and teachers [...]. Competent students [will] be able to provide coherent explanations, generate plans for problem solving, implement solution strategies and monitoring and adjusting their activities" (Anderson, 2008a, p. 49-50).

The roles of learners and lecturers also change. Although both "e-learners and traditional learners have access to a universe of digital information" (Johnson, Trabelsi \&Fabbro, 2008), in online learning, unlike in traditional learning, the process is more student-centered (Anderson, 2008a). Student is responsible for generating relevant knowledge, making relevant decisions on when, where and how to learn and which text, video, audio or picture to use. From an overwhelming range of information sources (Johnson, Trabelsi \& Fabbro, 2008) available online, an e-learner must choose and use the ones he/she prefers.

Traditional teachers need to get acquainted with online knowledge so that they become effective in the e-teaching and learning, which is the trend of the day. An e-teacher is a social, versatile and professional strategist who can "orchestrate, motivate, and assess effective learning" better than in traditional teaching and learning (Anderson, 2008 b, p. 360 ). Therefore, it is a matter of priority that lecturers be trained to be e-teachers (Caplan \& Graham, 2008). According to Caplan and Graham (2008), an online teacher must have specific 
pedagogical competencies as well as technical and administrative skills that allow him/her to conduct online teaching and learning in a virtual environment, with online learners, using specific material and strategies so as to capture students' interest, involvement, motivation, engagement and optimism (Morton, 2009, 59).

To successfully conduct online teaching and learning, the following qualities and responsibilities are essential (Caplan, Graham, 2008; Morton, 2009):

1. Ability to design relevant courses, use relevant materials and strategies, identify best platforms and tools for a smooth elearning;

2. Preview and allocate enough time for each e-activity;

3. Promote relevant student-student and student- teacher interaction;

4. Ability to provide not only relevant feedback, but also a relevant and clear feedforward;

5. Capacity to promote a collaborative learning among students;

6. Respect and consider different ideas, perspectives, talents and strategies of learning;

7. Aability to encourage students and clarify objectives and relevance of the course, each topic and e-activity;

8. To know and monitor how students learn;

9. Create an attractive virtual environment for learning purposes

While most of the time, teachers have large groups of students, making it difficult to conduct online learning, it is crucial to develop a spirit of togetherness and collaboration. In synchronous sessions, lecturers must encourage students to join the meetings in a specific period to avoid disruption of discussions because of late comers. Sessions also need to be timeously managed so that the concentration of the learners is not lost due to mismanagement of learning time. It is easy to get carried away and lose track as participants join session from their own spaces. There is a need to control students' microphones (they must keep them off, and turn them on when they want to speak) and discourage unnecessary students' chats and use of mobile phones (Morton, 2009).

The role of e-teacher, according to Craig, Goold, Coldwell and Mustard (2008), and Brenton in Fry, Ketteridge, Marshall, 2009) involves (1) producing or identifying relevant content, (2) moderating online discussions and activities, (3) playing a technical and/or administrative role responsible for answering student queries about the technology or course, (4) assessing students' learning and giving them both feedback and feedforward, (5) suggesting relevant platforms, materials and strategies for learning activities (6) counseling and researching.

This study therefore sought to investigate on online teaching and learning effectiveness during the Covid-19 Pandemic in one University in Zimbabwe. The study was guided by two research questions:

1. How did students rate the effectiveness of the online learning during the Covid 19 Pandemic?

2. What challenges did students encounter with the online learning during the Covid-19 Pandemic?

\section{Research Methodology}

This study employed the quantitative approach. Quantitative research consists of the use of statistical data which allows comparison and sometimes it is used to test hypothesis (Daniel, 2016).

Data collection was conducted through a survey by clicking on a link regarding online teaching and learning. The link was sent to a University lecturer at a higher learning institution in Zimbabwe, who was requested to provide the link to students doing online learning, encouraging them to act accordingly between the $1^{\text {st }}$ July 2020 and the $15^{\text {th }}$ February 2021, a period in which students were doing online learning as a strategy to overcome the negative impact of the pandemic of Covid-19 in the education sector. The relevance of this strategy is that it provided information given by students who participated in virtual learning adopted for the first time.

The study employed a convenient sampling whereby a total of 202 students responded to the questionnaire. Participants of both masculine and feminine genders, aging from 18 and above participated. The questionnaire comprised of two close-ended items about the effectiveness of the online learning and challenges encountered during the online learning sessions. Data was analysed descriptively and presented through graphs.

\section{Results and Discussion}

This section presents the results of the study based on the two research questions that guided the study. 
Research Question 1: How did students rate the effectiveness of the online learning during the Covid- 19 Pandemic?

Online teaching and learning are challenging to those institutions and societies that did not implement them before the emergence of the Covid-19 pandemic. Many institutions of Higher learning in the Southern African Region, and in developing countries particularly, adopted this modality of teaching and learning for the first time as a strategy to mitigate negative impact of the pandemic on the education sector. In Graph 1, the researcher presents results concerning the effectiveness of the e-learning process.

Analysis in Graph 1 reveals that, of 228 respondents, $63 \%$ affirmed that the process was not good and learning was difficult, $14 \%$ considered that the online learning was frustrating and they could not learn at all. Besides, $4 \%$ of students stated that the process was very good (they learnt better), whilst $19 \%$ considered it as normal, making a total of $23 \%$ of learners who were satisfied with the online learning approach.

\section{Graph 1: Perception of Students on the Online Learning Effectiveness during the Lockdown}

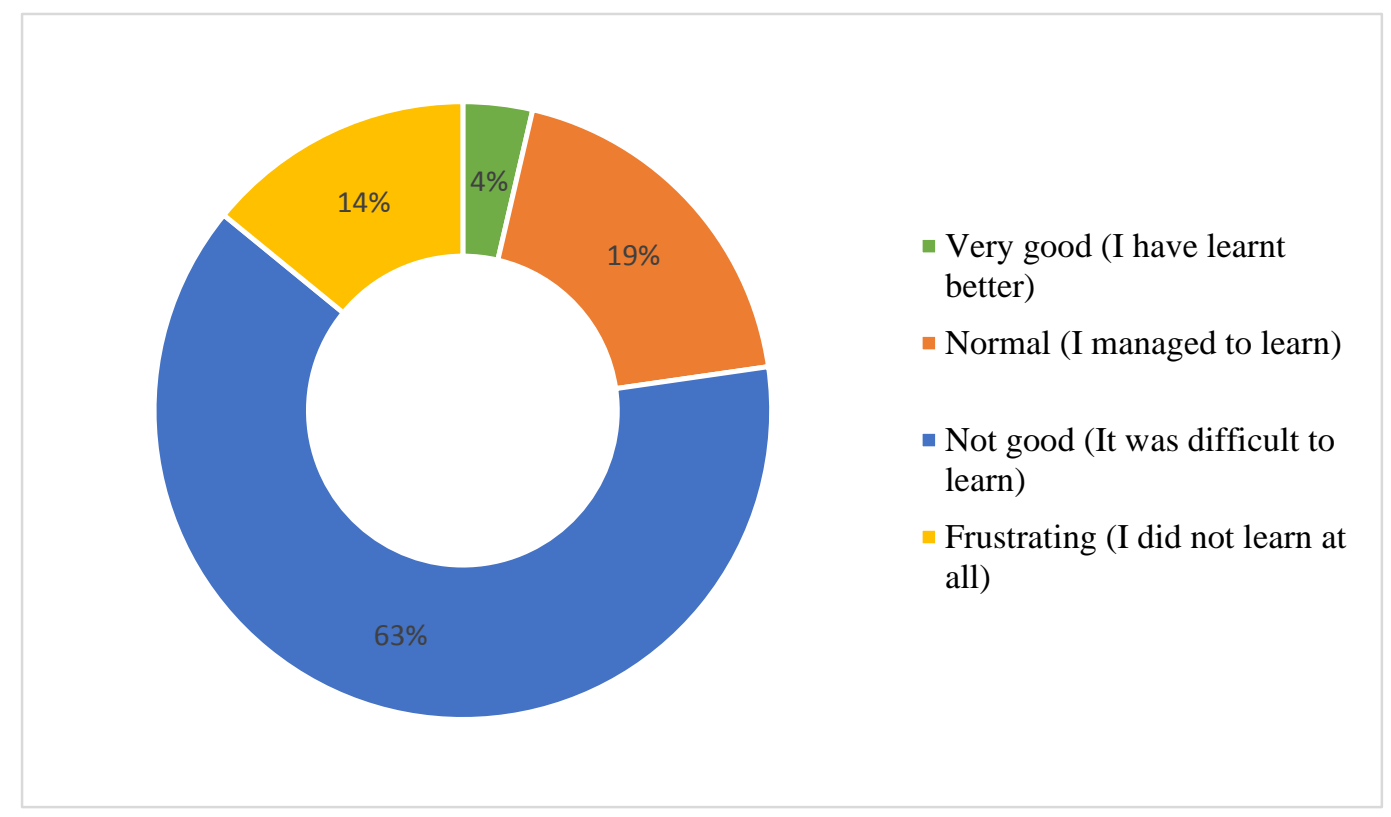

Graph 2: Challenges encountered during the online learning

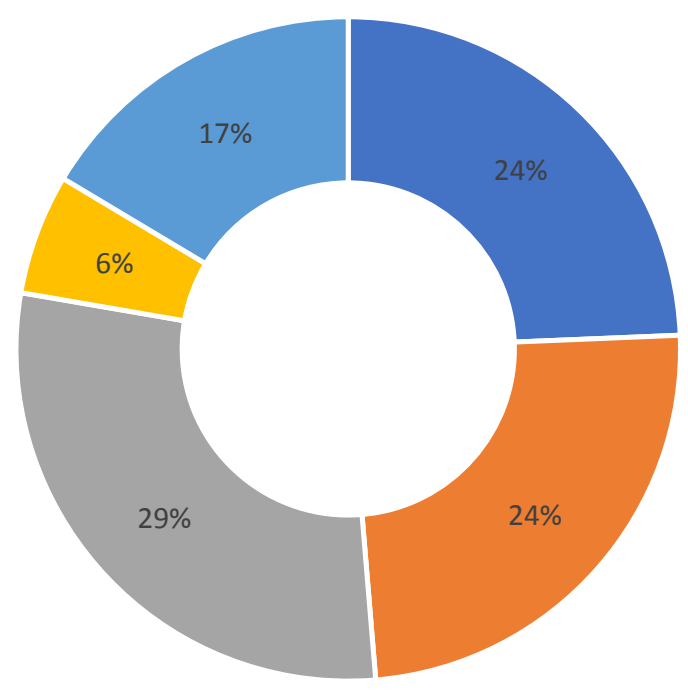

- Lecturer was just giving notes and sending assignments

- Lecturer could not give us a feedback

- It was difficult to communicate with the lecturer and other colleagues

- Everything was just monotonous

- The tests/assignments were not clear enough 
Research Question 2: What challenges did students encounter with the online learning during the Covid19 Pandemic?

The researcher required respondents to indicate specific challenges encountered during the teaching and learning process as reflected in Graph 2 (p. 59) which presents a number of challenges encountered by students during the process of learning.

The most cited challenge (29\%) has to do with communication as respondents indicated that it was difficult to communicate with lecturers and colleagues. This suggests that lecturers did not give feedback to the learners. According to Bakia, Shear, Toyama and Lasseter (2012), feedback is indispensable in the online learning process just as explanations, corrections and suggestions are vital in traditional teaching. The feedback enlightens students on what and how to improve and develop. Therefore, "giving effective online feedback is an important skill for educators to develop because it guides the learner's development" (Leibold, Schwarz, 2015, p. 34).

There are different types of feedback: (1) corrective feedback (specially to correct where students fail, be it in assignments or in the learning process), (2) epistemic feedback is when stimuli and questions are used for further comprehension and clarification), (3) suggestive feedback is an advice to improve learning, and (4) epistemic feedback which is used for further comprehension and suggests actions (Leibold and Schwarz, 2015).

Online learning does not necessarily isolate learners. It demands permanent and effective interaction between different entities. Lecturer-students and students-students communication/interaction is very relevant (Anderson, 2008a). An excellent eteacher needs to use both asynchronous and synchronous communication/interaction (Mendes et al., 2018, p. 11). Therefore, communication must be enhanced for an effective online learning to take place.

The second two aspects with $24 \%$ each have to do with teaching strategies as respondents indicated that lecturers were just giving notes and sending assignments and that the lecturers could not give feedback, which suggest a one way approach. Sending notes to students, especially university students, is harmful in an online teaching and learning processes. It blocks students' potential to research and develop critical thinking. Instead of just giving notes to students, the role of lecturers, according to Quiang (2018) and Anderson (2008b). includes providing topics to focus on, clarifying objectives and the relevance of each topic, suggesting relevant material, helping them to identify relevant ideas and to write notes, promoting and moderating discussion of ideas and theories, providing relevant feedback and feedforward, validating and approving and encouraging students to use their new knowledge to solve problems in their society. These approaches will provide new and genuine knowledge to the learners. Students will attest to their relevance in their learning and they will gain confidence and motivation. This is crucial for a successful online teaching and learning process.

The next aspect with $17 \%$ has to do with measurement of students' progress as respondents indicated that the tests and assignments were not clear enough. If teaching, learning and communication are not effective, it is natural that tests and assignments be unclear. To avoid that, the online teaching must be very clear and assessment must be done by various entities including the learner (self-assessment) as advocated by Amante and Oliveira, 2019). Failure to understand their tasks in test and assignments, in the context of online learning in which students have no relevant feedback, can lead to poor know-how and ability to solve problems, and consequently, students fail to meet expectations of the learning process.

Lastly, $6 \%$ of respondents indicated that everything was just monotonous which suggests that lecturers were not creative enough to create varieties of learning experiences. To overcome this challenge, lecturers are supposed to provide and recommend a variety of material in terms of videos, texts, voice notes, pictures, etc. about the same topic. This is very important for students to have access to different ideas and perspectives about the topic. It also promotes students' critical thinking.

\section{Conclusions and Recommendations}

It is concluded that the online teaching and learning process was not effective. Inefficient strategies used by lecturers are the main factors challenging the e-teaching and e-learning effectiveness as $29 \%$ of students stated that it was difficult to communicate with the lecturer and other colleagues, $24 \%$ revealed that lecturers just sent notes and assignments and could not give them effective feedback. Over $17 \%$ indicated that the 
tests/assignments were not clear enough, whilst 6\% complained that the learning was too monotonous.

It is recommended that Institutions of Higher Education in the Southern African Region should offer training programs on online teaching to their members of staff. Such initiatives will allow lecturers to develop relevant skills of an excellent e-teacher. This arrangement will allow effective teaching and learning to mitigate negative impacts of the Covid19 Pandemic

\section{References}

Ally, M. (2008) Foundations of educational theory for online learning. In: Anderson, T. (Ed.). The theory and practice of online learning. Canada: Au Press, p. 15-44.

Amante, L. \& oliveira, I. (2019). Avaliação e feedback. Desafios atuais. Lisboa; Universidade Aberta.

Anderson, $T$ (2008a). Towards a theory of online learning. In: Anderson, T. (Ed.). The theory and practice of online learning. Canada: Au Press.

Anderson, $\mathrm{T}$ (2008b) Teaching in an Online Learning Context. In: Anderson, T. (Ed.). The theory and practice of online learning. Canada: Au Press.

Bakia, M.; Shear, L.; Toyama, Y.; Lasseter, A. (2012) Understanding the Implications of Online Learning for Educational Productivity. Washington, Department of Education, Office of Educational Technology.

Bates, T. (2017). Educar na era digital [livro eletrônico]: design, ensino e aprendizagem. São Paulo: Artesanato Educacional (Coleção tecnologia educacional 8).

Caplan, D.; Graham, R. (2008) The development of online courses. In: Anderson, T. (ed.). The theory and practice of online learning. Canada: Au Press.

Craig, A; Goold, A.; Coldwell, J.; Mustard, J. (2008) Perceptions of Roles and Responsibilities in Online Learning: A Case Study. Interdisciplinary Journal of E-Learning and Learning Objects (4), 205-223.

Daniel, E. (2016). The usefulness of qualitative and quantitative approaches and methods in researching problem-solving ability in science education curriculum. Journal of Education and Practice 7(15), 91-100.
Davis, A; Little, P; Stewart, B (2008) Developing an infrastructure for online learning. In: Anderson, T. (Ed.). The theory and practice of online learning. Canada: Au Press.

Fry, H.; Ketteridge, S.; Marshall, S. (2009) Understanding student learning. $A$ handbook for teaching and learning in higher education: enhancing academic practice. New York: Routledge.

Johnson, K.; Trabelsi, H.; Fabbro, E. (2008). Library support for e-learners: e-resources, eservices, and the human factors. In: Anderson, T. (ed.). The theory and practice of online learning. Canada: Au Press.

Leibold, N.; Schwarz, L., M., (2015) The Art of Giving Online Feedback. The Journal of Effective Teaching, 15(1), 34-46.

Mendes, A. Q., Bastos, G. Amante, L., Aires, L. L. \& Cardoso, T. (2018). Modelo pedagógico virtual: Cenários de desenvolvimento. Lisboa: Universidade Aberta.

Meneses, E. L., Fernandez, G.D \& Regana, C. B. (2011). E-Actividades: elementos constitutivos para la calidad de la praxis educativa digital. In: Roig Vila, R. \& Laneve, C. (Eds.). La práctica educativa en la sociedad de la información. Innovación a través de la investigación. La pratica educativa nella società dell'informazione. L'innovazione attraverso la ricerca (pp. 267281). Alcoy - Brescia: Marfil \& La Scuola Editrice.

Moreira, A. (2018). Reconfigurando ecossistemas digitais de aprendizagem com tecnologias audiovisuais. Em REDE: Revista de Educação à Distância 5(1), 5-15.

Moreira, J. A. M \& Rigo, R. M. (2018). Definindo ecossistemas de aprendizagem em rede: Percepções de professores envolvidos em processos de formação. Debates em Educação 10(22), 107-120.

Morton, A. (2009) Lecturing to large groups. In Fry, H.; Ketteridge, S.; Marshall, S. (ed.) A handbook for teaching and learning in higher education: enhancing academic practice. New York: Routledge, p. 58-71.

Qiang, H. (2018) Examining Teachers' Roles in Online Learning. The EUROCALL Review 26(2), 1-18. 